\title{
Enforceability of Database Licensing Agreement: A Comparatives Study Between Malaysia and the United States of America
}

\author{
Nazura Abdul Manap \\ Faculty of Law, National University of Malaysia (UKM) \\ 43600 Bangi, Selangor, Malaysia \\ nazura@pkrisc.cc.ukm.my \\ Tel: 60-12-205-8669 E-mail: nazura@pkrisc.cc.ukm.my
}

\begin{abstract}
Licensing agreement is one of the mechanisms to secure the interest of database producers. A breach of any contractual term in the agreement will entitle a database producer to a contractual remedy. As regards to contractual protection, there are two important issues to be addressed. First, the clauses in the licensing agreement, and secondly, the issue of enforceability of certain database agreement, such as shrink wrap or click wrap license. The second issue must be resolved before a database producer is able to implement the terms and conditions provided in the database licensing agreement. This is because it determines the validity of the contract. With a valid contract, the contractual terms may be used to protect the interest of the database producers. The unconscionability of the terms in the database licensing seems to be a major issue. This issue arises due to the fact that the contractual terms are not read by licensee upon the conclusion of agreement and the inequality of bargaining power exists. Asymmetrical or unfair terms will cause unfairness to database users who will be prevented through the principle of undue influence or the common law doctrine of unconscionability. Although no clear statutory provision has provided a solution to the problem, there are two ways of dealing with it. First, the database producer must ensure that he does not use his dominant position to exercise unconscionable dealings. Secondly, it is advisable to incorporate a term providing that the buyer or user has the opportunity to reject the contract if he disagrees with the terms. To ensure the interest of the database producers the agreement should provide notice as to the database's terms of usage. This may form the basis of a breach of contract in the event that the stipulated terms are violated. A good contractual agreement is an agreement which protects the interest of both parties; i.e., the database producers and the users. To achieve that, both parties should come to a mutual agreement on the terms in the contract. The license should incorporate necessary provisions such as restrictions on use to protect the legitimate interest of the database producer. However licensees should also be given sufficient freedom to use the database content to meet their legitimate needs and should be prohibited from using the information in ways that would diminish the value of the database producer's investment in the database.
\end{abstract}

Keywords: Database, Licensing agreement, Enforceability, Unconscionability

\section{Introduction}

Since adhesion contracts have frequently been used in database dealing, there have been questions as to the validity and enforceability of such contract. The answers would determine whether or not these "shrink-wrap" or "click-wrap" licensing agreements would function as a shield to protect database products from exploitation. (Note 2)

How valid are these licenses? The validity of these "shrink-wrap" or "click-wrap" licenses is uncertain. Generally, the enforceability of these "shrink-wrap" or "click-wrap" licensing contracts is not absolutely clear. The main feature of these licenses is that it is a unilateral contract, in other words, both agreements are based on "take it or leave it". There is no good-faith bargaining of terms as there usually is in the ordinary contracts. The difference between "shrink-wrap" license and "click-wrap" license is that in the click wrap contract, (Note 3) the potential licensee has every opportunity to know the click-wrap's terms and conditions whereas under shrink wrap license, the potential licensee may have accepted the contract before having the opportunity to read the whole license.

Basically, the contractual problems pertaining to adhesion contract revolve around:

(1) Unconscionability issues. (Note 4) For example, unread terms (Note 5) and lack of mutuality of agreement. (Note 6)

(2) Formation of contract issues, i.e., issue on acceptance and the communication of acceptance;

In Malaysia, the answer to the above issues can basically be found in the Contracts Act 1950. The position of adhesion contract in Malaysia will be discussed together with the position in the United Kingdom and other relevant commonwealth countries. (Note 7) 


\section{Adhesion Contract: The Malaysian and Common Law Approach}

Firstly, we need to determine the position of online contracting. The Contracts Act 1950(Note 8) does not make any provision for the online environment. (Note 9) With the introduction of Electronic Commerce Act 2006 (ECA 2006) (Note 10), online contracting is recognized as all electronic transactions and shall not be denied legal effect, validity or enforceability on the ground that it is wholly or partly in an electronic form (Note 11).

The ECA 2006 has been restricted to only "commercial" transaction (Note 12). It has been argued that this restriction has excluded other important electronic transaction such as non-commercial unilateral communication, such as statement, declaration and notice (Note 13).

\subsection{Unconscionability of Agreement}

Even though the term "unconscionability" does not have a fixed meaning in law, (Note 14) in the context of contractual obligations, it applies to contracts that possess two elements. First, the contract's terms are unfair, and second, the party disadvantaged by the contract would not have entered it had he not been vulnerable in some respect. (Note 15) The equitable doctrine of unconscionability arises from the need to provide relief from unconscionable conduct. The question as to whether any conduct is unconscionable depends significantly on the particular facts of the case. (Note 16) Generally, unconscionable conduct can mean:

(1) A deficiency in either the bargaining process or the terms of the resulting transaction which operates as a vitiating factor to set aside a transaction; (Note 17)

(2) An organizing idea informing a specific equitable rules and doctrines which do not in terms refer to, or require an explicit finding of, unconscionable conduct, such as the rules or doctrine of estoppels, unilateral mistake, or undue influence; (Note 18)

(3) As a discrete doctrine for example as a ground to restrain a call on performance bonds. (Note 19)

Unconscionability of shrink wrap contract arises from the concern that contractual terms are not read by user before the conclusion of contract and the existence of inequality of bargaining power as they are constructed solely by the database producer. (Note 20) Yet, the doctrine of unconscionability has not been established properly in the Malaysian contract law. (Note 21) However, this doctrine has been widely developed in some other jurisdictions. In Australia, notably in Commercial Bank of Australia Ltd v. Amadio (Note 22), the court has clearly described the circumstances whereby this doctrine could be invoked. Dean J. in this case stated that: "The jurisdiction [to relieve against unconscionable dealing] is long established as extending to circumstances in which (i) a party to a transaction was under a special disability in dealing with the other party with the consequence that there was an absence of any reasonable degree of equality between them, and (ii) that disability was sufficiently evident to the stronger party to make it prima facie unfair or 'unconscentious' that he procure, or accept, the weaker party's assent to the impugned transaction in the circumstances in which he procured or accepted it. Where such circumstances are shown to have existed, an onus is cast upon the stronger party to show that the transaction was fair, just and reasonable." (Note 23)

The principle of unconscionability has been further explored by Lord Templemen in the Privy Council's decision of Boustany v. Pigott. (Note 24) The decisions above seem to suggest that a transaction may be regarded as unconscionable if there is inequality in the relationship between the parties to the contract and this position leads to unfair or unconscentious transactions. These 'unconscentious' dealings are reflected from the behaviour of the stronger party which are impropriety, power abusive and taking unfair advantage against the weaker party in the contract.

In Malaysia, whether or not inequality of bargaining power, as normally disputed in shrink wrap contract, (Note 25) be considered as unconscionable, is uncertain. Visu Sinnadurai J. in the case of Polygram Records Sdn Bhd v. The Search (Note 26), made no findings as to whether or not a contract may be set aside on the grounds of inequality of bargaining power. (Note 27) Although there is a possibility of invoking section 24(e) of the Contracts Act 1950 by reason of public policy, (Note 28) to set aside a contract on the ground of inequality of bargaining power, the application of this unconscionability doctrine are rarely done by the Malaysian courts except in Saad Marwi v. Chan Hwan Hua \& Anor(Note 29) and American International Assuarance Co. Ltd v. Koh Yen Bee.(Note 30)

Due to the absence of any established precedent on this aspect of law in Malaysia, it was submitted that the issue of unconscionability derives from the breach of the requirement of free consent. (Note 31) This requirement is reflected in section 10 of the Contracts Act 1950 which defines a contract as: “... all agreements made with the free consent of parties competent to contract ..."

Thus, factors which vitiate such consent (Note 32) will render the agreement voidable or to be precise, unenforceable contract at the option of the innocent party to the contract. These vitiating factors are stated in section 14 of the Contracts Act 1950 which illustrates that the consent is not a free consent if there are coercion, undue influence, fraud, misrepresentation and mistake of fact (Note 33).

Section 16 of the Act which deals with the concept of undue influence can also be invoked. (Note 34) This view is 
submitted on the basis that the courts in certain circumstances have established a relation between the doctrine of unconscionability and the principle of undue influence. In Credit Lyonnais Bank Nederland NV v. Burch, (Note 35) Millet LJ in this Court of Appeal's decision observed that the role of the doctrine of unconscionability would be established in the existence of the doctrine of undue influence coupled with the doctrine of infection. (Note 36) The learned judge opined that these two equitable concepts, i.e., unconscionable bargain and undue influence have many similarities. This is reflected from his views:

"In either case it is necessary to show that the conscience of the party who seeks to uphold the transaction was affected by notice, actual or constructive, of the impropriety by which it was obtained by the intermediary, and in either case the court may in a proper case infer the presence of impropriety from the terms of the transaction itself." (Note 37)

Concluding on the same point, Nourse LJ. observed that "... the unconscionability of the transaction remains of direct materiality to the case based on undue influence ...". (Note 38) In this particular case, it was said that the transaction was clearly and manifestly disadvantageous to the defendant. Thus, it was submitted from that decision that the doctrine of undue influence can be subsumed within a broader doctrine of unconscionability. (Note 39) However, it should be noted that this case was decided based on undue influence not merely on doctrine of unconscionability.

There are two conflicting views on whether unconscionable bargain or dealing is considered as a part of the statutory vitiating factors (under undue influence or coercion) or whether it exists independently? The first seems to suggest that the notion of unconscionability could exist independently of the general scheme of undue influence. The second view proposes that no discrete doctrine of unconscionability could arise from the statutory provision. The first view is supported by the decision in Chait Singh v. Budin bin Abdullah (Note 40) where since a good collateral contract had been provided, an interest charge at more than $18 \%$ on an illiterate man gave rise to the presumption of unconscionability. (Note 41) This case did not rely on the unconscionability principle derives from section 16 of the Contracts Act 1950. The court was obviously moved by the fact of the illiteracy of the Defendant. (Note 42) The second view predicates that no separate doctrine of unconscionability arise out of section 16(3) of the Contracts Act 1950. In other words, unconscionability as assumed in section 16(3) is a result arising from the occurrence of several sequences of acts, that is, a relation of dominance of one party over the other and the conclusion of agreement between them. The fact that the proof of unconscionability will then give rise to a rebuttable presumption that the agreement is induced by undue influence, will make this doctrine becomes so inseparably linked to the notion of undue influence and is incapable of independent existence. (Note 43) The Lord Justice said that a presumption of such a nature would not arise in the case of a man of better education. This opinion was supported by the judgment in Abdul Majeed v. Khirode Chandra Pal. (Note 44) where His Lordship stated that where ample security had been furnished, the exaction of excessive and usurious interests in itself raised the presumption of undue influence which requires little evidence to substantiate.

However, Lord Shaw in the Privy Council's of Ragunath Prasad v. Sarju Prasad (Note 45) decision was of the view that the principle laid down in Abdul Majeed v. Khirode Chandra Pal was wrongly made. Thus, in the light of the above decision, the case of Chait Singh v. Budin bin Abdullah (Note 46) must not be followed as it does not represent the correct view of section 16 (3)(a). Lord Shaw suggested that "There is no such presumption until the question has first been settled as to the lender being in a position to dominate the borrower's will". This indicated that the principle of unconscionability must be supported by undue influence. (Note 47)

Section 20 of the Contracts Act 1950 makes a contractual transaction voidable where consent to it is caused by undue influence. (Note 48) Undue influence, has not been clearly or accurately defined by the courts of law, however, it has been described as:

"... some unfair and improper conduct, some coercion from outside, some overreaching, some form of cheating and generally though not always, some personal advantage obtained by the guilty party..." (Note 49)

However, section 16(1) of the Contracts Act 1950 defines the circumstances in which a contract can be set aside on the ground of undue influence, first, where the relations subsisting between the parties are such that one of the parties is in a position to dominate the will of the other, and secondly, the party who is in a position to dominate the will of the other uses that position to obtain unfair advantage over the other.

The important question is what amounts to dominance? Section 16(2) of the Act specifies the situations where such dominance is presumed, first, where a person holds a real or apparent authority over the other, (Note 50) or secondly, where a person stands in a fiduciary relation to the other; (Note 51) or, thirdly, where he makes a contract with a person whose mental capacity is temporarily or permanently affected by reason of age, illness, or mental or bodily distress. (Note 52)

A database producer may be situated in the first position that is "holds a real or apparent authority over the other." Thus, in a contract of adhesion, it can be said that there is undue influence if the database producer has a real or apparent authority over the user. Therefore, if the database producer which is in a position to dominate the user had exercised unfair or unconscionable conduct and obtained unfair advantage over the user of the database, he is said to use undue 
influence in the contractual transaction.

The key word here is "dominance" where the turning point of the notion of undue influence relies on the existence of a relationship which endows on one party the position to dominate the will of the other. In Ragunath Prasad v. Sarju Prasad (Note 53) the Privy Council explained that the relationship between the parties must be such that one party was able to dominate the will of the other. Once that could be established, the next issue to be considered was whether one party by the use of that dominant position had obtained an unfair advantage over the other. (Note 54)

It seems from the relationship between database producer and the user it may be presumed that the "dominance" relationship exists as the database producer dominates the will of the user. The element of "dominance" is demonstrated in the facts that the end user is not involved in the making of the terms and conditions of the agreement. The content of the licensing agreement is determined solely by the database producer. No bargaining is involved in the making of this contract. The user is only left with a choice of whether to unwrap or not, if not, the user is not able to use or have access to the database content. However, the illustrations in section 16 of the Contract Act 1950 have given us the examples of "a position to dominate". Illustration (d) demonstrates a transaction that is considered as in the ordinary course of business which is not "induced by undue influence". Although in that illustration it seems that the banker has charged a high rate of interest of a loan by taking advantage of the stringency in the money market, it is not considered as in a position to dominate which may amount to undue influence. This indicates that to prove one's relationship is induced by undue influence is not an easy task. The claimant must show that the other party is in a position that he is able to influence the claimant to enter into contract such as this can be seen in a parental influence over a child (Note 55) and medical attendant influence over a man enfeebled by disease or age. (Note 56) Thus, taking the above argument into consideration, it is submitted that a database owner is not to be regarded as exercising undue influence over database user unless a fiduciary relationship or relationship of trust and confidence between him and the other party is established.

Despite the above attempt to apply the principle of undue influence to the act of inequality of bargaining power in a database licensing cases, it is believed that the application of section 16 of the Contract Act 1950 is very loose. The other alternative available is to apply the doctrine of unconscionability to overcome situations of inequality of bargaining power as found in the English doctrine of unconscionability. This is possible by virtue of section 3(1)(a) of the Civil Law Act 1956 which states that: “(1) Save so far as other provision has been made or may hereafter be made by any written law in force in Malaysia, the Court shall- (a) In West Malaysia or any part thereof, apply the common law of England and the rules of equity as administered in England on the 7th day of April 1956;"

This provision allows the application of the rules of common law and equity which suit to the local needs (Note 57).

As far as the issue of inequality of bargaining power is concerned, this provision applies as no specific written law in Malaysia deals with this issue in contracts. (Note 58) It has been submitted that section 16 of the Contracts Act 1950 deals with quite a different and much narrower doctrine. (Note 59) Adoption of English doctrine of unconscionability with a broad and liberal application as in Canada is the most just solution to the issue. (Note 60) This has made the doctrine of unconscionability in Malaysia as decided in Saad Marwi's case wider than the English position in Lloyds Bank Ltd v. Bundy (Note 61) which was rejected by the House of Lords in Westminster Bank Plc v. Morgan . (Note 62)

However, the importation of doctrine of unconscionability as suggested by Gopal Sri Ram JCA in Saad Marwi was regarded as doubtful in American International Assuarance Co. Ltd v. Koh Yen Bee. (Note 63) Abdul Hamid Mohamad JCA was of the view that:

"We do not wish to enter into an argument whether the doctrine of inequality of bargaining power or unconscionable contract may be imported to be part of our law. However, we must say that we have some doubts about it for the following reasons. First is the specific provision of s 14 of the Contracts Act 1950 which only recognizes coercion, undue influence, fraud, misrepresentation and mistake as factors that affect free consent. Secondly, the restrictive wording of s 3(1) of the Civil Law Act 1956, in particular, the opening words of that subsection, the cut-off date and the proviso thereto. Thirdly, the fact that the court by introducing such principles is in effect 'legislating' on substantive law with retrospective effect. Fourthly, the uncertainty of the law that it may cause." (Note 64)

Nevertheless, the court's stance on the decision of Saad Marwi was not a total rejection of the decision. This is reflected from the court's effort to distinguish the facts of the case from that of Saad Marwi. This demonstrates that the court admitted the need of doctrine of unconscionability to be applied to certain cases to ensure justice. Both of the above Court of Appeal's decisions have no definite approach. Perhaps Saad Marwi's case is more acceptable as it did not introducing new law but bringing in the common law doctrine through the process allowed in section 3(1) of the Civil Law Act 1976.

It is submitted that the application of the doctrine of unconscionability in Saad Marwi was not meant to legislate a statutory provision in our law. This English equitable principle should serve as a supplement to fill in the lacunae in the existing law. The issue of inequality of bargaining power in a database contractual licensing can be addressed in two 
ways. The first is by invoking the principle of undue influence under section 16 of the Contracts Act 1950. However, it seems that the application of this section has no concrete ground, particularly, when there is no single decided case to support it. The second is to apply the English equitable principle of unconscionability as suggested in Saad Marwi's case, i.e, via a statutory doors of section 3(1)(a) of the Civil Law Act 1956.

With regards to the latter, the English equitable principle of unconscionability may be applied in two ways. The first is through the interpretation of the court and the second through legislature. It was submitted by Abdul Hamid Mohamad JCA in American International Assuarance Co. Ltd v. Koh Yen Bee (Note 65) that in importing the doctrine of inequality of bargaining power or unconscionability into our law, the following reasons must be taken into account:

(1) The specific provision of section 14 of the Contracts Act 1950 which only recognizes coercion, undue influence, fraud, misrepresentation and mistake as factors that affect free consent;

(2) The restrictive wording of section 3(1) of the Civil Law Act 1956 which limits its application to the cut-off date and the proviso thereto;

(3) Introducing such doctrines is indirectly legislating a substantive law with retrospective effect; and

(4) The uncertainty of the law that it may cause.

The above grounds presents that the application of unconscionability doctrine should not be done without proper guidance. This common law principle may be introduced through statutory door of section 3(1) of the Civil Law Act 1956 subjects to certain conditions as follow:

(1) The court has to determine whether there is any written law in force in Malaysia;

(2) If there is none, then the court should determine what is common law as administered in England on $7^{\text {th }}$ April 1956 ( in West Malaysia);

(3) The court should consider whether 'local circumstances' and 'local inhabitants' permit its application. If it is permissible, the court should apply it. If not the court is free to reject it totally, or adopt any part which is permissible;

(4) If the court rejects the principle, then the court is free to formulate Malaysia's own common law by looking at other sources, local or otherwise including the common law of England after $7^{\text {th }}$ April 1956 and principles of common law in other countries. (Note 66)

A part from the application of common law principle and the formulation of Malaysia's own common law, the introduction of doctrine of unconscionability may be made through the amendment of the existing legislation or introducing new law. However, it is not for the court to decide but this role is played by Parliament through legislative power. (Note 67) In other words, this doctrine may be inserted in the Contracts Act 1950 through amendments of that statute or by introducing new law on this subject matter.

\subsection{Lack of Notice}

The enforceability of a contract depends on the existence of core elements; offer (Note 68) and acceptance, (Note 69) consideration and intention to create legal relationship. However, the first and second elements pose difficulties with regard to adhesion contract. There is no problem with offer. By virtue of section 7(1) of the ECA 2006, (Note 70) the advertisement for online database made in the website by the database owner to the users is an offer. Thus, a potential user can accept. (Note 71) by clicking the "Agree" or "Accept" button. (Note 72) But, to what extent clicking the "Agree' button is valid and contractually binds the party to the contract?

Once a potential user of the database clicks "Agree" or "OK" or "Accept" which appears on the screen, he is said to accept the terms and conditions set out together with the acceptance button. The user is usually given opportunity to read the terms prior to pushing the accept button. It is up to the user either to first read the terms and then clicking "Agree" or choose to point his mouse to the "Agree" button which, according to message on the screen that, deems that he has read the terms and are bound by those terms. (Note 73) A question arises as to whether terms and conditions in a license bind a party? The general principle is that once a party has signed a document, he is bound by those terms even if he has not read the terms. (Note 74) This principle has been applied in Malaysia as indicated in the case of Polygram Records Sdn Bhd v. Search \& Anor (Note 75) where the Visu Sinnadurai J. stated that:

"...The general principle of law, of course, is that a party who signs a written contract is bound by the terms of the contract, except in the limited cases where fraud, undue influence, or misrepresentation may be established. This rule is so strict that even if a party to a contract has not read the contents of a contract, he is held to be bound by its terms..." (Note 76)

From the above case, a conclusion can be made that there is an enforceable contract even though the user has not read the terms and conditions in the license agreement. But bear in mind that "not reading" the terms of the contract because the user opts not to do so and the fact that the user has "no opportunity to read" are two different situation. In the former, the strict rule of Polygram's case may be applicable. 
In that situation, the question arises whether adequate notice was given of the terms of the contract. (Note 77) According to the normal rules of offer and acceptance, the terms of the contract should be communicated to the offeree. This is to make sure that the offeree is aware of the nature and extent of the contract. (Note 78)

For shrink wrap licensing, a contract is made once the seal is broken, the opportunity to read the terms of the contract comes after the contract is made as this occurs when the package containing the database is handed over to the customer. Thus, in this circumstance, it is said that the terms and condition, which can be accessed after the package is unwrapped, are not part of the contract. This would render the terms ineffective and unenforceable. This contention is supported by the decision in Olley v. Marlborough Court Ltd, (Note 79) where the Court of Appeal held that the notice put in the room was not part of the contract. This is because it had been completed at the reception desk when the room had been paid for and the Plaintiff could not have seen it until after the contract was made. (Note 80) Unfortunately, this issue has not been addressed by the ECA 2006. (Note 81) Therefore in order to make the said terms and conditions part of the contract (Note 82) it was suggested that an ample notice to the existence of the terms and conditions must be drawn to the attention of the prospective database user. (Note 83) The notice must be brought to the contracting party before or at the time that the contract is made. If the offeree has actual knowledge of the terms, he is bound by it even though he has not read them or is unable to comprehend the terms. (Note 84) A notice after the conclusion of contract cannot be relied on. (Note 85 )

Thus, notice of the terms and conditions inside a database package must be placed where it is accessible by the prospective database user, to avoid post conclusion notice. If the notice is manifestly available and the offeree is able to read before tearing out the packaging, the terms and conditions inside the package are effective. Similar requirement applies to the click wrap license, if the database user is given notice as to the terms of the database agreement before he clicks "I Accept", the terms and conditions of the agreement are enforceable. In other words, the notice must be explicit.

In addition to that condition, the notice must be reasonably sufficient. Which means the notice must be brought to the attention of the party in a sufficiently displayed form to attract the attention of the party to the contract. This form may include a notice board and the way the terms is written in the contract itself. (Note 86) The principles were discussed in the case of Parker v. South Eastern Railway Co. (Note 87) where the Court of Appeal held that the question that had to be answered in this case was whether the Defendant had done what was reasonably sufficient to give the Plaintiff notice of the condition. (Note 88)

Applying the said principle to the database licensing agreement, for a shrink wrap contract to be enforceable, the terms of the license must be exposed on the outside of the package. As normally the CDROM is being wrapped in clear plastic, the license may be inspected before the package is opened. In this circumstance, the notice of the terms and conditions of the contract can be considered as reasonably sufficient. Another technique used to ensure that the notice is enforceable is that the licence is printed on a sealed packet containing the disk with a note stating that breaking the seals implies acceptance of the license. However this notice is usually accompanied with a promise that even after the seal is broken the user can return the disk in the event of the user being unwilling to accept the terms. (Note 89) As to the click wrap or browse wrap license, as long as there is a clear notice of the terms before the user clicks "Agree", such as, the user is asked to read the terms and conditions before accepting the agreement or the user is given opportunity to link to the other site which provides the terms and conditions of the license, in both these situations the notice of the contractual terms is regarded as reasonably sufficient to establish enforceable contract.

An acceptance of offer can be concluded from the words or documents that have passed between the parties to the contract or may be inferred from their conduct. (Note 90) Further analysis has to be made to a situation where a user of the database was allowed to get access to the information of database even though without having to click on the "Agree" button. (Note 91). In this case the act of acceptance would not be known to the offeror (database owner), or else no communication of acceptance has been made. (Note 92)

It is an accepted rule that silence cannot amount to acceptance. (Note 93) Therefore, without demonstrating whether or not the user agrees to the terms and conditions in the license may amount to an act of "silence". Thus, without acceptance, no contract has been formed. The same goes to the shrink wrap license as no communication of acceptance of offer occurs when the user breaks or unwraps the seal.

However, this position seems to be exempted in the following situation. According to section 7(b) (Note 94) of the Contracts Act 1950, that acceptance may be carried out in the manner in which the offerror has stipulated. In this case, by clicking the "Agree" button, the user is bound to the terms and conditions of the license. If the user deviates from the mode of acceptance specified by the offeror but straight away accesses to or downloads the data in the database, the offeror cannot merely keep silent. This would be a failure on his part to insist on the prescribed manner of acceptance, (Note 95) which would be considered as an acceptance of the modified form. (Note 96)

It is submitted that in a click wrap license, the rule that the offerror has prescribed the method of acceptance would be applicable. Thus, the user of database would be bound by the terms even if the user did not read the terms since he has 
accepted the contract by the stipulated method, i.e., by clicking "I Agree". This opinion is supported by section 8 of the Contracts Act 1950 whereby a performance of the conditions of a proposal is an acceptance of that proposal. (Note 97) The same issue has come to the attention of the Indian Court in the case of Hindusthan Co-operative Insurance Society Ltd v. Shyam Sunder \& Others, (Note 98) where the court was of the view that, "A mere tacit formation of intention cannot constitute an acceptance of an offer. Something more is required. There must be some overt act or speech from which that intention can be manifest." (Note 99)

This opinion confirms that there is contract even though no communication of acceptance is made to the offeree, i.e., the acceptance has not come to the knowledge of the offeror. The act of acceptance by conduct, in other words, does not require actual communication of acceptance is made; it suffices if the user of database accepts the offer by performing an act which is required in the terms of the contract, for example, by unwrapping the shrink wrap license or clicking "I Agree/Accept". In this situation, the offerror, i.e., the database producer, is not allowed to revoke the offer once the required conduct, unwrapping or clicking "Agree" has been performed by the database user.

The ECA 2006 has recognized online transactions. However, it is felt that, the ECA has not dealt with many issues such as notice.

\section{Adhesion Contract: The Position in the United States}

A few decided cases on enforceability of shrink-wrap licenses in the United States demonstrate that the said contracts were invalid on contract formation ground. (Note 100) Nevertheless, in a situation where the potential licensee has an opportunity to read the terms and conditions before un-wrapping the CD ROM package or clicking the "Agree" button, the contracts were considered as valid and enforceable. (Note 101)

In ProCD, Inc. v. Zeidenberg (Note 102) a database application is stored on CD ROM discs packaged, complete with a "how to" manual, in an appealing box encased in cellophane. The box displays a warning that the purchase of this product is subject to a restrictive licensing agreement. In fact, the licensing agreement appears each time the software is executed, forcing user to respond by pressing "Enter". The Defendant, an entrepreneurial computer programmer purchases a copy of the database and downloads the data in the CD ROM onto his computer. He then, uploads the data onto an Internet host computer. He develops his own software to access the downloaded database across the Internet and sells access to the Internet database for a fee. (Note 103) The Plaintiff comes to know about it and files suit alleging copyright infringement and a breach of licensing agreement.

Notwithstanding prior decisions, the Court broke new ground by enforcing the restrictive license in ProCD. (Note 104) The enforcement of the shrink wrap license afforded the ProCD exclusive rights in the database (Note 105) which would otherwise be unprotected under copyright law. The Court justified the decision on two grounds; first, the seller or licensor in a transaction has the power to impose conditions of acceptance on certain conduct by the buyer. Secondly, the defendant had an opportunity to review the license and was aware of the contract terms, but failed to object, thereby accepting them.

The enforceability of shrink-wrap license in Pro CD was based on contract law under the Uniform Commercial Code (UCC) by virtue of §2-204(1) UCC which states that:

"A contract for sale of goods may be made in any manner sufficient to show agreement, including conduct by both parties which recognizes the existence of such a contract..."

The second reason was based on $\S 2-606$ of the UCC. This section states that: “... [b] buyer accepts goods ... when, after an opportunity to inspect, he fails to make an effective rejection ..."

The acceptance of the offer occurred when, after the opportunity to inspect he fails to make an effective rejection. (Note 106) In this case, the defendant inspected the package, tried out the software, learned of the license, and did not reject the goods. (Note 107)

However, it was argued that although the buyer had notice of the restrictive license because the packaging displayed such a warning, the explicit terms of the license were not known to the buyer until he purchased the product. This leads to the issue of the unconscionability of the terms of the licensing agreement. This is one of the grounds of unenforceability of shrink wrap license. (Note 108)

However, in this case, the Court reasoned that the defendant had an opportunity to reject the product if he found the license terms to be unsatisfactory. The examples used included theatre tickets and airline tickets, where a purchaser is not aware of the terms of issue (placed on the reverse of the ticket), (Note 109) until after they have booked and paid for the ticket. However, the purchaser can return the ticket if they do not agree to the terms and conditions. A similar right of return existed in the present case; if the defendant did not agree to the licence terms, he could have returned the disk and receive a refund from the purchaser. Thus, the court considered that the licence would be binding on the defendant.

It is concluded that the element of surprise of the terms for such licenses, i.e., shrink wrap or click wrap, would not prevent the contract from being enforced, provided that, the buyer is given the opportunity to review the license terms 
and conditions and to reject should the buyer disagree with them.

The validity of shrink wrap license contract had been affirmed by subsequent cases for example in Hill v. Gateway. (Note 110) However, in this case, the Court noted that the buyer knew when ordering the product by phone that some sort of contract would likely be included in the transaction. In Micro Star v. Formgen Inc, (Note 111) the Court held that the defendant was bound by the restrictive terms even though no actual notice was given. The plaintiff had created a computer game that allowed and encouraged users to create new advanced levels of the game and to post them on the Internet so others could use them, the Defendant downloaded and copied these new user-made versions into CDs and resold them. The Court stated that users were prohibited by the license agreement from selling the user-made versions. Although, the restrictions were meant for the users who created the new-user made version, the defendant in this case was bound to the terms and conditions as the prohibition in the agreement evidenced the Plaintiff's intent to preserve its exclusive right to commercially distribute the work. However, the Court enforced rights against the defendant based on unknown contractual restrictions. This seems to suggest that as the users of the product they should know that there must be terms and conditions accompanied with the database in question. They have the obligations to seek out on which terms are digital products, such as database, are offered or risk being bound by default, at least to the extent of terms that are not unconscionable or otherwise illegal. (Note 112)

In click wrap licensing case Compuserv, Inc v. Patterson, (Note 113) the Court held that by typing "agree" on an online registration form, the Defendant had agreed to be bound by the terms of the shareware license that was displayed on the screen. Similarly in Hotmail Corp. v. Van\$ Money Pie, Inc (Note 114). The Court granted an injunction preventing the Defendant, a user of the Plaintiff's Internet email product from sending "spam" messages. The Defendant registered online and received several of the Plaintiff's email boxes. The terms of the online license agreement prohibited sending spam or obscene messages. It was held that there was a breach of contract as the Defendant had agreed to abide by the terms of the agreement by using the email boxes and had breached the contract by violating its terms.

Thus, both cases suggested that the act of agreement by the users or potential licensees is important to determine the issue on enforceability of adhesion contract. This is particularly relevant when the users are given the opportunity to read the terms and conditions attached to the click wrap or browse wrap license and by clicking "Agree" indicates that he or she understands the terms and conditions in the license and chooses to be bounded by them. Therefore, it is not unexceptional for the court in Specth v. Netscape Communications Corp., (Note 115) to hold that without clicking "Agree" the users are not bound to the license. The court in this "browse wrap' case, decided that where the user did not click "I agree" to the license before downloading the software they could not be bound by an agreement to arbitration which was on another web page, even where they were asked "Please review and agree to the terms of the ... license agreement before downloading and using the software".

The uncertain position of adhesion contract in the United States has encouraged the National Conference of Commissioners on Uniform State Laws to draft the Uniform Computer Information Transactions Act (UCITA) which adds Article 2B to the Uniform Commercial Code (UCC) to make shrink wrap license enforceable. The UCITA covers all "information transaction" and provides that a shrink wrap license is unenforceable unless, (i) the users has reason to know that more terms would be coming, (i) the users are given a right to return the product if they do not like the terms, (iii) the right to return is cost free and (iv) the users are reimbursed any reasonable costs of restoring the system if it was altered when they tried to read the license term. In conclusion, the UCITA permits database owners to enforce shrink wrap licenses as soon as a user unwraps a piece of CD ROM containing database, whether or not the terms have been read.

From the above picture, it indicates that the issue on enforceability of adhesion contract in the United States is assured with the enforcement of UCITA. However the same issues seemed to be unresolved in Malaysia. Unlike the Uniform Commercial Code of the United States, the ECA 2006 as well as the Contracts Act 1950 is silent on the provision of effective rejection. With this provision, even though there is an element of surprise in the terms, the user nonetheless, has the opportunity to reject the contract if he disagrees with the terms.

As this is a "take it or leave it" basis of agreement, a one-sided terms or unfair terms will be a central issue here. Nevertheless, as indicated above, the issue of unconscionability, in the principle of undue influence, can be avoided if the database producer does not use his dominant position to exercise unconscionable dealings.

In circumventing the issues of unconscionability in an adhesion contract, it is submitted that the database agreement should incorporate a clause stating that if the user does not agree with any of the terms he is free to withdraw from the contract by making affirmative rejection to the contract. This clause seems to provide protection not only to the users of the database, but also the database producer as it ensures the validity of the agreement. Although the transaction involves contractual terms which will be made available only after the contract has been entered into, the contract is valid as it will be subject to the later terms which allow the users to reject the terms and terminate the contract. In addition to that, the users should be able to obtain a full refund and to be compensated for any cost involved which includes any costs involved in returning the product and any reasonable and foreseeable cost of restoring the user's 
computer should this prove to be necessary.

By constructing a fair agreement for both parties, no dispute on the enforceability of contract may arise. This will ensure protection to the interest of both the database producers and the users of the database.

\section{Conclusion}

It is undeniable that licensing agreements can be invoked to protect the interest of database producers. The clauses in the licensing agreement protects database producer or usually known as licensor in the agreement. In other words, if the licensee breaches the terms, the licensor will be entitled to remedy under the contract. However, the protection offered by licensing is not that strong. This view is substantiated by the facts that the licenses only bind the contracting parties, whereas other regime like copyright, it is good against the whole world. Contractual protections do not work against third parties who are not party to the licensing agreement. They may manipulate the data, which are initially restricted, as they please. This can be done particularly with the assistance of digital technologies which allow a quick, easy and cheap digital copying. The third parties would include a hacker or someone accessing the database in an unauthorized manner or for unauthorized purposes for instance, a person who enter the database through "back door" methods. The unauthorized accessor might never encounter the agreement to where he or she is supposedly bound. In this circumstance, the parties could use the database in any manner they so chose, and the database producer would have no contractual recourse. Despite the above, a database licensing agreement provides notice as to the database's rules of use, and may form the basis of a breach of contract in the event that the stipulated terms are violated. It is important to note that, problems relating to unenforceability of adhesion contract must be resolved before a database producer is able to implement the terms and conditions provided in the database licensing agreement. Once the agreement is free from those predicaments, it may be used to protect the interest of the database producers.

\section{References}

\section{Journals Publication}

Abu Bakar Munir, Siti Hajar Mohd Yasin, "Electronic Commerce Bill 2006: An Oversight or Wanting a Different or...?" (2006) 4 MLJ i.

Cheong May Fong, "A Malaysian Doctrine of Inequality of Bargaining Power and Unconscionability After Saad Marwi" (2005) 4 MLJ i at v.

E.Leonard Rubin, "Understanding the Intellectual Property License: Database and Content Licensing”, 2004806 PLI/Pat 537,

Ida Madieha Azmi, "Contract or Copyright? Software Licensing and the Control of Information Products: The Malaysian Perspective.” C.T.L.R. 2001, 7(6), 136-142, at 139.

J. Davidson, Scott J. Bergs, Open, "Click or Download What have You Agreed To? The Possibilities Seem Endles", (1999) 557 PLI/PAT 687 at 700.

Shaik Mohd Noor Alam bin SM Hussein, "Pre-Contractual Fairness: Sections 15 and 16 of the Malaysian Contracts Act 1950", (1993) 2 MLJ cxxxi, (1993) 2 MLJA 121.

\section{Books}

Andrew Phang. (1998). Law of Contract: First Singapore and Malaysian Student's Edition, Butterworths Asia, Singapore.

Halsbury's Laws of Malaysia; Conflict of Laws, Equity, Volume 26, at 264.

J. Beatson, Anson's Law of Contract, $27^{\text {th }}$ Edition, Oxford.

Julian Ding. (1999). E-Commerce; Law \& Practice, Sweet \& Maxwell Asia.

N.Stephen Kinsella, Andrew F. Simpson. (2004). Online Contract Formation, First Edition, Oceana Publications.

Salleh Buang dan Nordin Torji. (1992). Undang-Undang Kontrak di Malaysia, Central Law Book Company, Kuala Lumpur.

Stephen A. Smith. (2004). Contract Theory, Clarendon Law Series, Oxford University Press.

\section{Notes}

Note 1. The author (Nazura Abdul Manap) would like to thank Associate Professor Dr. Abdul Mohaimin Noordin Ayus for his critical and valuable commentaries on this article.

Note 2. These agreements operate as "contracts of adhesion" which are non-negotiable and pre-printed forms offered on a "take it or leave it" basis. The party who accepts the contract does not negotiate, but merely adheres. Most of the consumer-oriented database licensing agreements are not signed. These unsigned licensing agreements purport to bind 
licensees by action not signature. These databases provide notices which warn potential licensees that accessing the database indicates acceptance by the licensee of the terms and conditions in the license agreement. Thus, the conduct of the potential licensee who clicks on the notice or unwrap the package before entering the database binds the licensee to the contract.

Note 3. 'Click- wrap' or 'web-wrap' licenses are easy to find on the Internet For example, the Internet provider has one that the user agreed to before using the service for the first time.

Note 4. In Comb v.Paypal, Inc, 218F. Supp. 2 d 77 (N.D.Cal.2002) the court questioned that whether without a record of the assent of both parties there is an enforceable agreement and found that the arbitration clause in PayPal's user agreement is unconscionable. Ibid.

Note 5. The nature of adhesion contract, i.e., the shrink-wrap agreements have deprived the users' right to affirmatively search for and read the licensed terms before choosing either to object or be bound by them (unread terms), J. Davidson, Scott J. Bergs, Open, "Click or Download What have You Agreed To? The Possibilities Seem Endles", 1999557 PLI/PAT 687 at 700 .

Note 6. The essential elements of an agreement are competent parties, subject matter, a legal consideration, mutuality of agreement and mutuality of obligation. Corey W. Roush, "Database Legislation: Changing Technologies require Revised laws", 200228 U. Dayton L.Rev.269, at 300. Thus, they lack of mutuality of agreement and obligation as there has not been an opportunity to negotiate the terms of the contract. Even if the terms are enforceable, they cannot materially alter the terms of the original contract. Ida Madieha Azmi, "Contract or Copyright? Software Licensing and the Control of Information Products: The Malaysian Perspective." C.T.L.R. 2001, 7(6), 136-142, at 139.

Note 7. This is done as the Malaysian contract has it basis from the English common law principles.

Note 8 . The validity of an adhesion contract is assessed based on the fact that the database contract is contractual licensing not a contract of sales of goods. The difference between these two types of contracts is the former does not involve transfer of ownership to the buyer whereas the latter does.

Note 9. N.Stephen Kinsella, Andrew F. Simpson, Online Contract Formation, First Edition, Oceana Publications, 2004, at 161.

Note 10. Act 658. This law has come into forced at 19 October 2006 (P.U. (B) 280/2006.

Note 11. Section 6(1) of the Electronic Commerce Act 1998

Note 12. Ibid, Section 2.

Note 13. Abu Bakar Munir, Siti Hajar Mohd Yasin, "Electronic Commerce Bill 2006: An Oversight or Wanting a Different or...?" (2006) 4 MLJ i.

Note 14. Stephen A. Smith, Contract Theory, Clarendon Law Series, Oxford University Press, 2004, at 340.

Note 15. Ibid.

Note 16. Halsbury's Laws of Malaysia; Conflict of Laws, Equity, Volume 26, at 264. See also note 1 which states that in the context of performance bonds, the Singapore Court of Appeal in Dauphin Offshore Engineering \& Trading Pte Ltd $v$ The Private Office of HRH Sheikh Sultan bin Khalifa (2001) 1 SLR 657 at 663 said: 'What kind of situation would constitute unconscionability would have to depend on the facts of each case...There is no pre-determined categorisation'.

Note 17. Ibid.

Note 18. Ibid.

Note 19. Ibid.

Note20. Ingle v. Circuit City Stores, Inc., 328 F.3d 1165 (9th Cir. 2003), cert. denied 540 U.S. 1160. See also Blake v. Ecker, 93 Cal. App. 4th at 742 at 743.

Note 21. Shaik Mohd Noor Alam bin SM Hussein, "Pre-Contractual Fairness: Sections 15 and 16 of the Malaysian Contracts Act 1950", (1993) 2 MLJ cxxxi, (1993) 2 MLJA 121. The issue of unread terms is considered as pre-contractual issue as it is done before the contract is concluded.

Note 22. (1983) 151 CLR 447, (1983) 46 ALR 402.

Note 23. (1983) 46 ALR 402 at 423.

Note 24. (1993) 63 P \& CR 298 at 312. In delivering the judgment of the Board, his Lordship put down a compilation of principles relating to unconscionability, which includes:

"(1) It is not sufficient to attract the jurisdiction of equity to prove that a bargain is hard, unreasonable or foolish; it must be proved to be unconscionable, in the sense that 'one of the parties to it has imposed the objectionable terms in a 
morally reprehensible manner, that is to say, in a way which affects his conscience: Multiservice Bookbinding v Marden. (2) 'Unconscionable' relates not merely to the terms of the bargain but to the behaviour of the stronger party, which must be characterized by some moral culpability or impropriety: Lobb (Alec) (Garages) Ltd v Total oil (Great Britain) Ltd.

(3) Unequal bargaining power or objectively unreasonable terms provide no basis for equitable interference in the absence of unconscentious or extortionate abuse of power where exceptionally, and as a matter of common fairness, 'it was not right that the strong should be allowed to push the weak to the wall'; Lobb (Alec) (Garages) Ltd v Total oil (Great Britain) Ltd.

(4) A contract cannot be set aside in equity as 'an unconscionable bargain' against a party innocent of actual or constructive fraud. Even if the terms of the contract are "unfair' in the sense that they are more favourable to one party than the other ('contractual imbalance'), equity will not provide relief unless the beneficiary is guilty of unconscionable conduct: Hart v. O'Connor applied in Nichols v. Jessup. ${ }^{1}$

(5) 'In situations of this kind it is necessary for the plaintiff who seeks relief to establish unconscionable conduct, namely that unconscentious advantage has been taken of his disabling condition or circumstances': per Mason $\mathrm{J}$ in Commercial Bank of Australia Ltd v. Amadio."

Note 25. Ingle v. Circuit City Stores, Inc., 328 F.3d 1165 (9th Cir. 2003), cert. denied 540 U.S. 1160. See also Blake v. Ecker, 93 Cal.App.4th at 742 at 743.

Note 26. (1994) 3 MLJ 127.

Note 27. Ibid. at 160.

Note 28. As suggested in the Indian Supreme Court decision of Central Inland Water Transport Corp Ltd v. Brojo Nath Ganguly AIR 1986 Supreme Court 1571.

Note 29. (2001) 3 CLJ 98.

Note 30. (2002) 4 MLJ 301.

Note 31.Shaik Mohd Noor Alam bin SM Hussein, Pre-Contractual Fairness: Sections 15 and 16 of the Malaysian Contracts Act 1950, at cxxxi, at 121. This view is supported by the facts that unconscionable conduct can mean a deficiency in either the bargaining process or the terms of the resulting transaction which operates as a vitiating factor to set aside a transaction. Halsbury's Laws of Malaysia; Conflict of Laws, Equity, Volume 26, at 264.

Note 32. A contract can be unenforceable on the basis of vitiating factors. These vitiating factors are based on the improper conduct of one party, the vulnerability of the other or the combination of the two. J.Beatson, Anson's Law of Contract, $27^{\text {th }}$ Edition, Oxford, at 270

Note 33. Salleh Buang dan Nordin Torji, Undang-Undang Kontrak di Malaysia, Central Law Book Company, Kuala Lumpur, 1992, 147.

Note 34. Section 16 ("Undue Influence) states that "A contract is said to be induced by "undue influence" where the relations subsisting between the parties are such that one of the parties is in a position to dominate the will of the other and uses that position to obtain an unfair advantage over the other..." Contracts that are voidable under section 16 of the Contracts Act 1950 for undue influence can be separated into two categories, firstly, those where there is no special relationship between the parties; secondly, those where a special relationship exists. Section 16(2)(a) of the Contracts Act 1950.

Note 35. (1997) 4 All ER 144.

Note 36. This doctrine of infection was said to be "...under certain circumstances, knowledge of the actions of a person who has actually been guilty of the exercise of undue influence (whether actual or presumed) can be "brought home", as it were, to the party who desires to enforce her rights under the contract. If such knowledge can in fact be "brought home', then the party so desiring to enforce her rights will be "infected' by the guilty person's conduct and will consequently be precluded from enforcing her rights; in other words, the effect would be as if the party so desiring to enforce the rights had actually perpetrated the undue influence herself..." Andrew Phang, Law of Contract: First Singapore and Malaysian Student's Edition, Butterworths Asia, Singapore, 1998, at 374.

Note 37. (1997) 4 All ER 144 at 153. Milett's LJ was of the view that the transaction was not merely manifestly disadvantageous to the defendant but was also one that 'shocks the conscience of the court'.

Note 38. (1997) 4 All ER 144 at 151.

Note 39. Andrew Phang, Law of Contract: First Singapore and Malaysian Student's Edition, Butterworths Asia, at 391. 
Note 40. (1922) 1 FMSLR 348

Note 41. The case concerned a money lending transaction between the Plaintiff, a Sikh moneylender and the defendant, a Malay farmer. The Plaintiff sued the defendant on a pro-note which provided for interest at the rate of $36 \%$ per annum. The Defendant had deposited his mukim register extracts with the Plaintiff as collateral security. Mr Justice Innes, the acting chief judicial commissioner held that since good collateral had been provided, an interest charge at more than $18 \%$ on an illiterate man gave rise to the presumption of unconscionability. Shaik Mohd Noor Alam bin SM Hussein, "Pre-Contractual Fairness: Sections 15 and 16 of the Malaysian Contracts Act 1950", at cxxxi, at 121.

Note 42. Ibid.

Note 43. Ibid.

Note 44. (1915) 42 Cal 690 at 699.

Note 45. AIR 1924 PC 60.

Note 46. (1922) 1 FMSLR 348.

Note 47. Section 16(3) of the Contract Enactment that had been discussed in Chait Singh v. Budin bin Abdullah (1922) 1 FMSLR 348 is pari materia with section 16(3) of the Contracts Act 1950.

Note 48. Section 20 (Power to set aside contract induced by undue influence) states that: “...When consent to an agreement is caused by undue influence, the agreement is a contract voidable at the option of the party whose consent was so caused. Any such contract may be set aside either absolutely or, if the party who was entitled to avoid it has received any benefit thereunder, upon such terms and conditions as to the court may seem just..."

Note 49. Andrew Phang, Law of Contract: First Singapore and Malaysian Students Edition, Butterworths Asia, Singapore, 363.

Note 50. Section 16(2) (a) of the Contracts Act 1950.

Note 51. Ibid.

Note 52. Section 16(2) (b) of the Contracts Act 1950.

Note 53. AIR 1924 PC 60. This case discussed on the scope of section 16 of the Indian Contracts Act which is in pari materia with the Malaysian Contracts Act.

Note 54 . As stated by the Privy Council in the above case:

“...even though the bargain had been unconscionable (and it has the appearance of being so ) a remedy under the Indian Contracts Act does not come into view until the initial fact of a position to dominate the will has been established..." Ibid. pp. 64-65.

Note 55. Illustration (a) of section 16 of the Contracts Act 1950.

Note 56. Ibid, Illustration (b).

Note 57. See Lee Kee Chong v. Empat Nombor Ekor (NS) Sdn Bhd \& Ors (1976) 2 MLJ 93; Chung Khiaw Bank Ltd v. Hotel Rasa Sayang Sdn Bhd \& Anor. (1990) 1 CLJ 675.

Note 58. Gopal Sri Ram JCA in Saad Marwi v. Chan Hwan Hua \& Anor (2001)3 CLJ 98 at 115.

Note 59. Ibid.

Note 60. Ibid. pp. 115-116.

Note 61. (1975) QB 326 at 335. Lord Denning in his judgment said that: "Gathering all together, I would suggest that through all these instances there runs a single thread. They rest on "inequality of bargaining power." By virtue of it, the English law gives relief to one who, without independent advice, enters into a contract upon terms which are very unfair or transfers property for a consideration which is grossly inadequate, when his bargaining power is grievously impaired by reason of his own needs or desires, or by his own ignorance or infirmity, coupled with undue influences or pressures brought to bear on him by or for the benefit of the other."

See Cheong May Fong, "A Malaysian Doctrine of Inequality of Bargaining Power and Unconscionability After Saad Marwi" (2005) 4 MLJ i at v.

Note 62. (1985) 1 All ER 821. Lord Scarman in that case was of the view that:"The question which the House does have to answer is: did the court in Lloyds Bank Ltd v Bundy accurately state the law? Lord Denning MR believed that the doctrine of undue influence could be subsumed under a general principle that English courts will grant relief where there has been 'inequality of bargaining power' (see (1974) 3 All ER 757 at 765, (1975) QB 326 at 339). He deliberately avoided reference to the will of one party being dominated or overcome by another. The majority of the court did not follow him they based their decision on the orthodox view of the doctrine as expounded in Allcard v Skinner (1887) 36 
Ch D 145, (1886-90) All ER Rep 90. This opinion of Lord Denning MR, therefore, was not the ground of the court's decision, which has to be found in the view of the majority, for whom Sir Eric Sachs delivered the leading judgment."

See Cheong May Fong, "A Malaysian Doctrine of Inequality of Bargaining Power and Unconscionability After Saad Marwi" (2005) 4 MLJ i at v.

Note 63. (2002) 4 MLJ 301.

Note 64. Ibid. pp. 319.

Note 65. (2002)4 MLJ 301 at 319.

Note 66. Judgement by Abdul Hamid Mohamad FCJ in Majlis Perbandaran Ampang Jaya v. Steven Phoa Cheng Loon \& Ors (2006) 2 MLJ 389 at 414.

Note 67. Ibid at 415.

Note 68. Section 2 (a) of the Contracts Act 1950 defines an offer or proposal as “...when one person signifies to another his willingness to do or to abstain from doing anything, with a view to obtaining the assent of that other to act or abstinence he is said to make a proposal..."

Note 69. Section 2(b) of the Contracts Act defines an acceptance as "...when the person to whom the proposal is made signifies his assent thereto, the proposal is said to be accepted; a proposal, when accepted, becomes a promise..."

Note 70. This section states that "...In the formation of a contract, the communication of proposals, acceptance of proposals, and revocation of proposals and acceptances or any related communication may be expressed by an electronic message..."

Note 71. To hold otherwise would imply that there would never be a contract until the database owner agrees to the offer made by each and every potential user and he is required to inform each potential user of his intention to perform the contract in order to ensure that there is an enforceable contract. Therefore, if this is the case, then to avoid unenforceability of contract the database owner should clearly stipulate that a response from the user of the site to the advertisement constitutes an offer. It is actually depends on the intention of the database owner whether to treat the advertisement as an offer or mere advertisement which will only amount to invitation to treat. N.Stephan Kinsella, Andrew F.Simpson, Online Contract Formation, at 163.

Note 72. The communication of acceptance, according to, the Contracts Act 1950 can be either through postal rule or instantaneous communication. This is highlighted in section 4(2) of the Act, where it provides that: “...The communication of an acceptance is complete- (a) as against the proposer, when it is put in the course of transmission to him, so as to be out of the power of the acceptor; and (b) as against the acceptor, when it comes to the knowledge of the proposer. Hence, the validity and enforcement of all communications of proposals, acceptance and revocation would be determined in accordance with these rules. It is submitted that this click-through mode of acceptance resembles that of instantaneous communication. Ibid.

Note 73. Julian Ding, E-Commerce; Law \& Practice, Sweet \& Maxwell Asia, 1999, at 60.

Note 74. Subject to vitiating factors, such as when fraud, undue influence, or misrepresentation is established. Polygram Records Sdn Bhd v. Search \& Anor1994] 3MLJ 127 at 147.

Note 75. (1994) 3 MLJ 127.

Note 76. Ibid. at 147. The court came to the decision by referring to the leading case of $L^{\prime} E s t r a n g e ~ v F$ Graucob [1934] 2 KB 394, Scrutton LJ pronounced (at p 403): “...When a document containing contractual terms is signed, then, in the absence of fraud, or, I will add, misrepresentation, the party signing it is bound, and it is wholly immaterial whether he has read the document or not.

Note 77. A basic rule of contract law is that it is not possible particularly in unilateral contract, to introduce new terms into a contract after it has been made. David I Bainbridge, Introduction to Computer Law, $4^{\text {th }}$ Edition, Pearson Education, 2000, 238.

Note 78. J.Beatson, Anson's Law of Contract, at 162.

Note 79. (1949) 1 All ER 127. In this case a husband and wife went to a hotel paid for a room. Their room contained a notice excluding liability for articles lost or stolen unless handed to the manageress for safe custody. A fur coat belonging to the wife was stolen and the hotel sought to rely on the exclusion notice. It was held that the notice was ineffective and the hotel was liable for the loss of the coat on the ground of negligence.

Note 80. See also contrasting cases dealing with tickets; Thompson v, LMS Railway (1930) 1 KB 41, Chapelton v. Barry Urban District Council (1940) 1 All ER 356.

Note 81 . The Act only focuses on general contract formation. It has been suggested that other communications 
concerning the performance of contractual obligations such as relevant notices or statements may be issued in the electronic message should be addressed in that section. Abu Bakar Munir, Siti Hajar Mohd Yasin, "Electronic Commerce Bill 2006: An Oversight or Wanting a Different or...?” (2006) 4 MLJ i.

Note 82 . Therefore to be absolutely sure that the terms in the license are part of the contract the database user should be asked to sign the license before the package is handed over. However, in many situations, this is impracticable particularly when the delivery of the database makes it not possible to do so for example where the database is acquired through mail order. David I Bainbridge, Introduction to Computer Law, 239.

Note 83.Interfoto Picture Library Ltd v. Stiletto Visual Programmes Ltd (1988) 1 All ER 348.

Note 84 . Provided that the offeree has not been misled by fraud or misrepresentation. J.Beatson, Anson's Law of Contract, at 160-161.

Note 85. In Thornton v. Shoe Lane Parking Ltd. Lord Denning (1971) 1 All ER 686 in His Lordship's decision stated that: "The custom customer pays his money and gets a ticket. He cannot refuse it. He cannot get his money back. He may protest to the machine, even swear at it... He is committed beyond recall. He is committed at the very moment when he puts his money into the machine. The contract was concluded at that time...The offer is made when the proprietor of the machine holds it out as being ready to receive the money. The acceptance takes place when the customer puts his money into the slot...he is not bound by the terms of the ticket...because the ticket comes too late. The contract has already been made."

This issue was also discussed in the Malaysian case of Goh Gok Hoon v Eusuff Bros. Sdn.Bhd (1990) 2 MLJ 421.

Note 86. In Spurling (J) Ltd v. Bradshaw (1956) 2 All ER 121. Lord Denning was of the view that the more unreasonable the clause is, the greater the notice which must be given in some cases, in order to give sufficient notice, it would need to be printed in red ink and a red hand pointing to it, or something equally startling.

Note 87. (1877) 2 C.P.D, 416 at 421 . In this case the plaintiff deposited a bag in the defendant's station cloakroom. He received a paper ticket which said on its face 'See back' and on the back were a number of printed conditions, including a condition limiting liability for any package to $£ 10$. The plaintiff admitted that he knew there was writing on the ticket, but stated that he had not read it, and did not know or believe that the writing contained conditions. The bag was lost, and the plaintiff claimed $£ 2410$ s for its value.

Note 88. To what extent the notice is sufficiently available is a question of fact which depends substantially on the circumstances of the case and the situation of the parties. The case of Thompson v. L.M. \& S. Railway Co. (1931) 1 K.B. 41 represents a liberal approach to what constitutes reasonable notice. ${ }^{1}$ In this case it was held that a clause exempting the company from liability, printed in its time table was sufficiently incorporated into the contract since the ticket referred to the timetables and excursion bills. However, the situation is different in Richardson, Spence \& Co. v. Rowntree, (1894) A.C. 217 where a term limiting the liability of the steamship company to $\$ 100$ as stated in the ticket was held not to be incorporated. This was due to the fact that the ticked had been handed to the plaintiff folded up and the terms were eradicated by the red ink stamping on the parts of the ticket. The notice was said to be insufficient as the plaintiff could not read the conditions even though she knew the terms were there. Thus, it can be concluded that the notice is considered as sufficient if the way the terms is displayed is as such that it attracts the attention of the offeree and he is able to read it, see Malaysian Airlines System v. Malini Nathan (1986) 1 MLJ 330.

Note 89. David I Bainbridge, Introduction to Computer Law, at 238.

Note 90. Andrew Phang, Law of Contract: First Singapore and Malaysian Student's Edition, at 82.

Note 91. As discussed above, it was decided by the court in Specth v. Netscape Communications Corp 150 F.Supp.2d 585 (S.D.N.Y.2001), that to hold that without clicking "Agree" the users are not bound to the license. The court in this "browse wrap' case, decided that where the user did not click "I agree" to the license before downloading the software they could not be bound by an agreement to arbitration which was on another web page, even where they were asked "Please review and agree to the terms of the ...license agreement before downloading and using the software".

Note 92. Section 4(2) of the Contracts Act 1950 states that "...The communication of an acceptance is complete (a) as against the proposer, when it is put in a course of transmission to him, so as to be out of the power of the acceptor; and (b) as against the acceptor, when it comes to the knowledge of the proposer...".

Note 93. An offerror may not arbitrarily impose contractual liability upon an offeree merely by proclaiming that silence shall be deemed consent. In Felthouse v. Bindley, (1862) 11 CBNS 869, the Court of Common Pleas held that the action must fail as there had been no acceptance of the plaintiff's offer before 25 February, and the plaintiff had therefore, at that date, no title to maintain conversion. Andrew Phang, Law of Contract: First Singapore and Malaysian Student's Edition, at 94.

Note 94. Section 7(b) of the Contracts Act 1950 states that “...In order to convert a proposal into a promise the 
acceptance must-be expressed in some usual and reasonable manner, unless the proposal prescribes the manner in which it is to be accepted. If the proposal prescribes a manner in which it is to be accepted, and the acceptance is not made in that manner, the proposer may, within a reasonable time after the acceptance is communicated to him, insist that his proposal shall be accepted in the prescribed manner, and not otherwise; but if he fails to do so, he accepts the acceptance..."

Note 95. It is an accepted rule of contract law that if one party submits an acceptance of an offer which contains other terms, then that particular new terms are considered as a counter offer. A counter offer is a new offer which means the previous offer has not been accepted, thus no contract is formed.

Note 96. See section 7(b) of the Contracts Act 1950. Compare this position to English cases (common law rule) in Tinn $v$ Hoffman \& Co, (1873) 29 LT 271, Manchester Diocesan Council for Education v Commercial and General Investments Ltd, (1970) 1 WLR 241. Julian Ding, E-Commerce; Law \& Practice, at 61.

Note 97. Section 8 of the Contracts Act 1950 on acceptance by performing conditions, or receiving consideration states that "...Performance of the conditions of a proposal, or the acceptance of any consideration for a reciprocal promise which may be offered with a proposal, is an acceptance of the proposal..."

Note 98. AIR 1952 Calcutta 691.

Note 99. Ibid, at 692. See also the old case of Weatherby and Another v. Banham (1832) 5 C \& P 228, 172 ER 950.

Note 100. Stephen J. Davidson, Scott J.Bergs, Open, Click or Download What have You Agreed To? The Possibilities Seem Endless, at 700. Vault Corporation v Squaid Software Ltd 655 F.Supp.750, 761 (E.D. La 1987), aff'd, 847 F.2d 255 ( $5^{\text {th }}$ Cir. 1988),, Foresight Resources Corporations v. Pfortmiller 719 F.Supp. 1006 (D.Kan, 1989)., Step-Saver Data Systems, Inc. v. Wyse Technology 939 F. 2d 91 (3d Cir.1991)., Arizona Retail Systems, Inc. v. The Software Link 831 F. Supp. 759 (D Ariz. 1993).

Note 101. E.Leonard Rubin, "Understanding the Intellectual Property License: Database and Content Licensing", 2004806 PLI/Pat 537, at 547-548.

Note 102. 908 F Supp 640 (W.D. Wis. 1996), reversed and remanded, 86 F3d 1447 (u 7thCir 1996). The Plaintiff, J-CAP Directories, Inc, specializing in a computer disc technology, invested \$10 million in researching and developing a comprehensive telephone database. The researchers compile 95 million listings and incorporate them into electronic database. The listings include residential and commercial names, addresses and telephone numbers. This database application enables the computer user to search using any number of fields, i.e., name, town, state, zip code, industry code and telephone area code.

Note 103. The Defendant accomplishes all this less than three months with the investment of only $\$ 50,000$.

Note 104. The District Court case decided that the licensing agreement unenforceable under contract law. However, the Seventh Circuit reversed this holding and further held that the shrink wrap license, imposing restrictions on an end-user, was enforceable. 86 F3d 1447 ( $7^{\text {th }}$ Cir 1996), at 1449.

Note 105. The court effectively (1) extended database protection by preventing the end-user from copying the database application, (2) by-passed copyright's first sale doctrine; (3) permitted an ambiguous acceptance of contract terms following the purchase of a product, and, (4) ignored the doctrine of fair use.

Note 106. As stated under $\S 2-602$ (1) of the UCC.

Note 107. 86 F3d 1447 ( $7^{\text {th }}$ Cir 1996), at 1453.

Note 108. Ida Madieha Azmi, "Contract or Copyright? Software Licensing and the Control of Information Products: The Malaysian Perspective". C.T.L.R. 2001, 7(6), 136-142, at 136. See also Stephen J.Davidson, Scott J.Bergs, Open, Click or Download What have You Agreed To? The Possibilities Seem Endless, 1999557 PLI/PAT 687, at 702.

Note 109. 86 F. 3d 1447 (7thCir 1996), at 1453.

Note 110. 105 F. 3d 1147 ( $7^{\text {th }}$ Cir. 1997), In this case the court held that an arbitration agreement packaged inside a computer shipping box was enforceable despite the fact that the original agreement between the parties took place over the phone and no mention of the specific license terns was made at that point of time.

Note 111. 154 F. 3d 113 ( $9^{\text {th }}$ Cir. 1999)

Note 112. Stephen J. Davidson, Scott J. Bergs, Open, "Click or Download What have You Agreed To? The Possibilities Seem Endless", 1999557 PLI/PAT 687, at 702.

Note 113. 89 F.3d 1257 ( $6^{\text {th }}$ Cir. 1996) at 1264. However, the formation of the contract was not the primary issue in the case. Instead, the court stated that a contract had been formed in the context of a discussion of whether the defendant was subject to personal jurisdiction in Ohio, where the plaintiff's computer and operation resided. 
Note 114. 1998 WL 388389 (N.D. Cal., April 16, 1998).

Note 115. 150 F. Supp.2d 585 (S.D.N.Y.2001). 